\title{
The Reluctant Martyr: John Hart's English Mission
}

\author{
Mordechai Feingold \\ California Institute of Technology \\ feingold@hss.caltech.edu
}

\begin{abstract}
In chronicles of early Catholic missions to England, John Hart (d.1586) comes across as something of an embarrassment. Slated to be executed alongside Edmund Campion on December 1, 1581, at the last moment Hart chose life over martyrdom. In exchange for his freedom he volunteered to spy on William Allen, president of the English College in Rheims. Equally embarrassing, in the context of the charged religious and political atmosphere of the early 1580 s, when put to the test as a scholar, Hart revealed weakness instead of strength in his conference with John Rainolds. Though this basic story line is known and often summarily retold, few scholars have delved into the intricacies of the affair - an omission this article seeks to remedy.
\end{abstract}

\section{Keywords}

John Hart - Jesuits - English mission - John Rainolds - religious controversies - martyrs

In chronicles of early Catholic missions to England, John Hart (d.1586) comes across as something of an embarrassment. ${ }^{1}$ Slated to be executed alongside Edmund Campion (1540-81) on December 1, 1581, at the last moment Hart chose life over martyrdom. In exchange for his freedom he volunteered to spy on William Allen (1532-94), president of the English College in Rheims. Equally embarrassing, in the context of the charged religious and political atmosphere of the early 1580 , when put to the test as a scholar, Hart revealed weakness instead of strength, even conceding to his Protestant antagonist, John Rainolds

1 I wish to thank Mauro Brunello, Victor Houliston, Gerard Kilroy, Thomas McCoog, Carol Magun, Michael Questier, Stefania Tutino, Jonathan Woolfson, and several referees for their helpful comments.

(C) MORDECHAI FEINGOLD, 2019 | DOI:10.1163/22141332-00604004

This is an open access article distributed under the terms of the prevailing CC-BY-NC license at the time of publication. 
(1549-1607), that important tenet of early modern Catholicism: the deposing power of popes. Though this basic story line is known and often summarily retold, few scholars have delved into the intricacies—and perhaps even the obfuscations - of Hart's rise and fall for reasons I can only suppose are rooted in a deep-seated discomfit with missionaries who lost heart, at least temporarily. ${ }^{2}$

A careful reconstruction of Hart's career enables the presentation of a consummate micro-history, crucial for the elucidation of a wide range of issues that cannot only be hinted in this article. First, my focus is on an individual who happened to be the intimate protégé of William Allen, as well as an instrument of propaganda in the hands of Robert Persons (1546-1610): the two architects of the English mission, who envisaged martyrdom as an indispensable means for the re-conversion of England. "No one," as one scholar noted, "was more resolute than William Allen about martyrdom's potential for working conversion." Indeed, a month before Campion's execution, Allen went so far as to express his conviction that in martyrdom Campion would further the Catholic cause far more than through his success in disputation. ${ }^{3}$ For his part, Persons was of the belief "that God's presence and affirmation of martyrdom was to be found in the martyrdom itself." In a letter he drafted five days before Campion was sent to the gallows, he exclaimed: "What greter matter of comfort can there be to us that ar Catholikes then to see God worke these strange wonders in our dayes for thadvauncement of his and our cause, that is to geve suche rare grace of zeale, austerytie of lyef and constancy of martirdom unto yonge men."4 Inspired by such an outlook, the missionaries crossed the Channel in 1580 expecting (or even hoping) to die - the very destiny that was publicly embraced by Hart.

To be sure, Catholics often embraced the Augustinian conception of martyrdom- "martyrem non facit poena, sed causa"-as Thomas Harding $(1516-72)$ did when denigrating the Marian Protestant martyrs: "It is not death that justifieth the cause of dying; but it is the cause of dying that justifieth the death." In principle, therefore, clinging to life need not have excluded Hart

2 See, in general, Patrick McGrath, "Apostate and Naughty Priests in England under Elizabeth I," in Aidan Bellinger, ed., Opening the Scrolls: Essays in Catholic History in Honour of Godfrey Anstruther (Bath: Downside Abbey, 1987), 50-83.

3 Brad S. Gregory, Salvation at Stake: Christian Martyrdom in Early Modern Europe (Cambridge, MA: Harvard University Press, 2001), 283; Letters of William Allen and Richard Barrett, 15721598, ed. P. Renold (London: Catholic Record Society, 1967), 35.

4 The Correspondence and Unpublished Papers of Robert Persons, SJ, volume 1: 1574-1588, ed. Victor Houliston, Ginevra Crosignani, and Thomas M. McCoog (Toronto: Pontifical Institute of Mediaeval Studies, 2018), 246-47.

5 Thomas Harding, A confutation of a booke intituled An apologie of the Church of England (Antwerp: John Laet, 1565), 14. For the Augustinian dictum, see Gregory, Salvation at Stake. 
from among the ranks of those readily enduring torment for the sake of the true Catholic faith. The question is, and this is my second point, to what extent did the likes of Hart remain true to the cause notwithstanding their temporary loss of heart? The present study suggests that a more nuanced approach to contemporary conceptions of "ideological purity" is necessary in order to fully appreciate the continuum between martyrdom and apostasy. Human nature, in particular, played as significant a role in the calculus of missionaries' deeds, as did political exigencies and programmatic considerations. In his introduction to "The True and Wonderful Story of the Lamentable Fall of Anthony Tyrrell," Persons acknowledged the many "causes, reasons, and motives of such as fall" in England, which included "fear, frailty, [and] desire of life" — but only in order to celebrate the contrary urge, "of rising again and returning unto us," which he wrongly believed to have been the case with Anthony Tyrrell (1552-1610). ${ }^{6}$

For the most part, however, conceding weakness was tantamount to admission of failure. Persons and other propagandists doggedly drew an idyllic portrait of Catholic prisoners and martyrs, depicting them as superior to their captors in faith, virtue, and learning. The analysis below suggests that greater caution is required in interpreting these texts. Hart dissembled with his co-religionistswho may well have been partly aware of this - as much as he did with his captors, and he surely was not alone to do so. At the same time, Hart's letters, Tower diary, and his personal interactions with Persons and Allen, crucially informed the contemporaneous construction of martyrology narratives.

Finally, our case study offers a unique perspective on another central feature of the English mission, and of early modern Catholicism more generally: scholarship. At least since John Jewel $\left(15^{22-71}\right)$ issued his famous challenge sermon in 1559 and 156o, the question of which side possessed superior learning became a highly contested issue between the warring parties, and the architects of the mission made the subject integral to their propaganda effort. William Allen not only extolled the learning of individual missionaries but he "even went so far as to suggest that intellectual distinction was one of the reasons why priests were executed [...] 'divers of them were farre better lerned then any of their sect could withstand."'7 Persons concurred. In a 1580 letter to Alfonso Agazzari (1549-1602) detailing the growing persecution of Catholics in England, Persons added: "When they first came into this island, the Jesuits heard that the cunning of their adversaries was such that, if they

6 John Morris, The Troubles of Our Catholic Forefathers Related by Themselves, 3 vols. (London: Burns \& Oates, 1872-1877), 2:316. Tyrrell lapsed again while Persons prepared the priest's confession for the press, which rendered publication pointless.

7 William Allen, A Briefe Historie of the Glorious Martyrdom of XII Reverend Priests (Rheims: Foigny, 1582), sig. aiii. 
captured any men who were distinguished for learning [...] they were wont to keep them shut up in dark prisons $[. .$.$] never allowing them to defend their$ cause in public." ${ }^{8}$

Yet, despite recognizing the centrality of intellectual attainments to the mission, recent scholarship focused, almost exclusively, on Campion's "heroic" performance during the disputations in the Tower of London. However, Campion's brilliance was exceptional, as were the conditions under which he was made to dispute. Hart's lengthy exchange with John Rainolds, in contrast, though devoid of the flare that had distinguished Campion's performance, was conducted on more equal footings: Hart was not tortured; he was provided with books; and he appears to have had quite a say in the process leading to publication. Moreover, the Conference better reflects the extent to which a much more advanced level of erudition was introduced into confessional debates. Coming close on the heels of Campion's purported triumph, Hart's failure to measure up to Rainolds's scholarship dampened the triumphalism of Catholic propagandists, especially as they had proclaimed victory well before the published version of the Conference appeared. More importantly, however, The Summe of the Conference Betwene John Rainoldes and John Hart Touching the Head and the Faith of the Church, is not "a partial, sensational work, building parodies and trying to exploit a captive and [...] unwilling priest." ${ }^{\prime \prime}$ By his own admission Hart, like his fellow missionaries, were just as eager to dispute as Campion was. And, again, while the Conference as not carried out on an equal footing, it does represent a unique solemn disputation between a Catholic and a Protestant, not to be repeated during Elizabeth's reign (r.1558-1603).

Hart was probably born in the early 1550 in Eynsham, Oxfordshire. ${ }^{10}$ His father, William, never wavered in his commitment to the old faith. In 1571, he had been implicated in a scheme involving Mary Queen of Scots (1542-87), and five years later he and his wife were indicted for hearing a Mass. He may or may not have been the William Hart of Bicester, who appeared on a 1584 list of Oxfordshire residents charged with hosting priests, and who was summoned two years later to appear before the Privy Council. A William Hart, "gentleman," is also found on a 1592 list of Oxfordshire recusants. ${ }^{11}$ In addition to John, William

8 Persons, Correspondence, 129.

9 Joshua Rodda, Public Religious Disputation in England, 1558-1626 (Aldershot: Ashgate, 2014), 26.

10 According to Bartoli, Hart was about the same age as William Weston, who was born in 1550. Daniello Bartoli, Dell'Istoria della Compagnia di Giesu: L'Inghilterra parte dell'Europa (Rome: Recaldini, 1667), 292.

11 Historical Manuscript Commission, Calendar of the Manuscripts of the [...] Marquis of Salisbury, 24 vols. (London, 1883-1976), 1:500, 4:270; Alan Davidson, "Roman Catholicism 
fathered two other sons and two daughters. Thomas Hart of Eynsham is listed in the 1577 diocesan returns as owning goods valued at £10o. On October 10, 1580, four months after John had been apprehended, Thomas appeared before the Privy Council, and "was willed from time to time to give his attendance to understand ther Lordships further pleasure, and not to depart without their speciall license to the contrary."12 William, the youngest son, followed in John's footsteps. He was born in 1561 and was already a student of the English College in Rome on April 23, 1579, when the institution was placed under the supervision of the Society of Jesus. When Pope Gregory XIII (r.1572-85) visited the college on August 12, 1579, William joined his namesake-the future martyr William Hart-in greeting the pope with Latin orations, which so pleased the pontiff that he promised to bestow a large sum of money on the fledgling college. Admitted as a novice to the Jesuit order in 1582 , William died in college on August 6, $1584 .{ }^{13}$ The two sisters, Elizabeth and Margaret, are to be found as early as 1571 on a list of "fugitive over the seas," alongside their brother John, described as "Yoman." According to an English spy, it was John who had persuaded his father to send his sisters to the Continent. ${ }^{14}$ Another tally of Catholics abroad, compiled a decade later, described the daughters of "William Hart of Eynsham gent," as nuns at Rouen..$^{15}$ They belonged to the Bridgettine Convent of Sion at Rouen, which relocated in 1594 to Lisbon. Elizabeth became abbess in 1606, dying three years later; her sister died in $1628 .{ }^{16}$

Nothing is known for certain about Hart's life prior to his leaving England. According to Anthony Wood, he had been "educated in most kinds of literature" at Oxford, ${ }^{17}$ but his name does not appear on any college or university

in Oxfordshire from the Late Elizabethan Period to the Civil War (c.1580-c.1640)" (PhD diss., University of Bristol, 1970), 264, 405.

12 Patrick Ryan, "Diocesan Returns of Recusants for England and Wales 1577," Catholic Record Society, Miscellanea XII (London, 1921), 1-114, at 110; John R. Dasent, ed., Acts of the Privy Council of England, 46 vols. (London, 1890-1964), 12:240.

13 Henry Foley, S.J, Records of the English Province of the Society of Jesus, 7 vols. in 8 (London: Burns \& Oates, 1875-83), 7/1:340; Clare Talbot, ed., Miscellanea: Recusant Records (London: Catholic Record Society, 1961), 218.

14 Talbot, Miscellanea, 243.

15 Davidson, "Roman Catholicism in Oxfordshire," 116-17; Thomas F. Knox, ed., The First and Second Diaries of the English College, Douay (London: David Nutt, 1878), 362.

16 William Croft, Historical Account of Lisbon College (Barnet: St. Andrews Press, 1902), 209; Caroline Bowden, "Books and Reading at Syon Abbey, Lisbon, in the Seventeenth Century," in E. A. Jones and Alexandra Walsham, eds., Syon Abbey and Its Books: Reading, Writing and Religion in England, c.1400-1700 (Woodbridge: Boydell, 2010), 177-202, at 178-79.

17 Anthony Wood, Athenae Oxonienses, ed. Philip Bliss, 4 vols. (London: Rivington, 1813-20), 1:635. 
register. In all likelihood, he studied in Oxford during the second half of the 156os, and perhaps even met there his future opponent, John Rainolds. He may have also made the acquaintance of William Camden (1551-1623), who entered Magdalen College in 1566 and transferred to Christ Church a year and a half later. Decades afterwards, when writing about the 1580 Catholic mission, Camden singled out Hart as possessing "singular learning above the rest"-an assessment that might have been based, at least in part, on personal knowledge. ${ }^{18}$ In light of subsequent events, Anthony Wood's characterization of Hart as a "very unsettled and wavering in mind" is equally worth noting. ${ }^{19}$

Hart probably left for the Continent shortly before matriculating on February 28,1569 at the University of Leuven. ${ }^{20}$ In the following year, he joined a distinguished group of English Catholic scholars, mostly from Oxford, who entered the recently founded English College in Douay, including Gregory Martin (1542-82) and Campion. ${ }^{21}$ It is not known how long Hart remained in Douay; an English spy recorded $c .1574$ that he had departed some time earlier "towards Rome."22 Another spy recorded later that Hart's father had approved of the trip and bestowed a pension on his son while abroad. ${ }^{23}$

Hart appears to have travelled in the company of three other Englishmen. The identity of two of them- "Mr Butler" and "Mr Fitzwilliam" —is difficult to establish. The third companion was the enterprising and well-connected Nicholas Wendon. A former fellow of Trinity College, Cambridge, MA (1554), Wendon subscribed in 1555 to the Catholic articles and was collated two years later as rector of Minster-in-Thanet, Kent. The religious shift that occurred following the ascension of Elizabeth to the throne hardly affected Wendon's fortunes, notwithstanding his reluctance to conform. In April 1559, he was appointed archdeacon of Suffolk; two years later, Thomas Seckford, Elizabeth's masterin-ordinary of the Court of Requests, recommended Wendon to Archbishop Parker as a person worthy of a prebendary stall in Norwich cathedral, and the archbishop acquiesced. ${ }^{24}$ Wendon spent much of his time on the Continent. He acquired a doctorate of canon and civil law, probably from Leuven, and

18 William Camden, Annales the True and Royall History of the Famous Empresse Elizabeth (London: For Benjamin Fisher, 1625), 58 (second pagination).

19 Wood, Athenae Oxonienses, 1:635.

$20 \quad$ Matricule de l'Université de Louvain, vol. 4 (February 1528-February 1569), ed. A. Schillings (Brussels: Kiessling \& Imbreghts, 1961), 748.

21 Knox, Douay Diaries, 4-5.

22 TNA SP 12/105/10; Knox, Douay Diaries, 301.

23 Talbot, Miscellanea, 204, 212.

24 Correspondence of Matthew Parker, D.D., Archbishop of Canterbury, ed. John Bruce (Cambridge: Cambridge University Press, 1853), 142. 
in 1567 he was admitted to Doctors' Commons. ${ }^{25}$ In 1572 , Wendon received a three-year leave to travel abroad, from which he never returned. Despite his long absences and suspected religious beliefs, Wendon was ejected from his canonry only in 1570 , and he managed to hang on to his archdeaconry until 1575 . By January 29,1577 , his name is found on a list of religious fugitives abroad-alongside Hart. ${ }^{26}$

I think it necessary to expand on Wendon's career because he may have served as a mentor of sorts to Hart. On June 7,1574 , a John Hart, son of William Hart, received a doctorate in both civil and canon law at the University of Padua. Wendon's presence at the ceremony may support the conclusion that the candidate was our John Hart, and that Wendon encouraged his young companion to follow in his footsteps. ${ }^{27}$ At the ceremony, performed in the house of the count palatine Marco Mantova Benavides, Hart was examined and promoted to the degree, after taking the required oath of Catholic faith. Witnesses to the ceremony, in addition to Wendon, were Sir Philip Sidney (1554-86), who may have known Hart at Oxford whilst a student there between 1568 and 1571; Ralph Hopton, the son of Sir Owen Hopton, lieutenant of the London Tower and Sidney's companion; Griffin Maddox, Sidney's amanuensis; James Randolph, consiliarius and electionarius of the English nation, 1576-78; and Richard Walker, a medical student. ${ }^{28}$

Later that year, Hart and Wendon proceeded to Rome in time for the opening of the 1575 jubilee year. There, the two undoubtedly encountered other former Oxonians, including Persons, John Lane, and Henry Garnet. And if a clerical vocation had not been previously high on Wendon and Hart's minds, the fervor of the festivities touched them, too. Wendon accepted the clerical tonsure on January 21 and, on April 2, he was ordained subdeacon by Bishop Thomas Goldwell (1501-85). Hart received minor orders from Bishop Goldwell on May

25 George D. Squibb, Doctors' Commons: A History of the College of Advocates and Doctors of Law (Oxford: Clarendon Press, 1977), 157.

26 J. B. Wainewright, "Archdeacons Deprived under Queen Elizabeth," Ampleforth Journal 17 (1911): 1-7, at 6; Thomas F. Mayer and Courtney B. Walters, The Correspondence of Reginald Pole, Volume 4: A Biographical Companion; The British Isles (Aldershot: Ashgate, 2008), 568; John Strype, Annals of the Reformation, 4 vols. in 7 (Oxford: Clarendon Press, 1824), 2/2:596-97.

27 It is not entirely certain that it was John Hart the missionary who took the degree, for we find another Doctor John Hart in Rome several years later. See my "The Other John Hart," Notes \& Queries 66 (2019): 59-63.

28 Jonathan Woolfson, Padua and the Tudors (Toronto: University of Toronto Press, 1998), 23, $52,243,266$. 
1 and 3 at the English Hospice. ${ }^{29}$ According to Daniello Bartoli (1608-85), Hart even joined William Weston (1550-1615) in becoming a postulant and wearing a cassock at St. Andrew's novitiate in Rome, though he ultimately changed his mind. ${ }^{30}$ Be that as it may, a few weeks later, the two again headed north. Wendon remained in Cambrai, where he had been awarded a canonry, ${ }^{31}$ while Hart continued to Douay to embark on his theological studies. He performed the three acts required for the degree of bachelor of theology on August 21, 1576 , November 28,1577 , and January $20,1578,{ }^{32}$ and then traveled to Cambrai, where he was ordained priest five weeks after Wendon's own ordination. ${ }^{33}$ By then, local opposition to the English Catholics necessitated the relocation of the English College to Rheims, with Hart moving thither on April 9, 1578. ${ }^{34}$ In the following year, Hart was appointed catechist.

On August 27, 1579, William Allen left for Rome, having been summoned by Pope Gregory XIII to quell infighting between English and Welsh scholars at the English College. While there, Allen helped plan a new Catholic mission to England, which would include, for the first time, members of the Jesuit order. The mission was to be led by the septuagenarian Thomas Goldwell, and the sixty-year-old Nicholas Morton (1521-87). Also selected were four Marian priests (Edward Bromberg, Thomas Crane, William Giblet, and William Kemp); three priests from the English College (Luke Kirby [1549-82], Edward Rishton, and Ralph Sherwin [1550-81]); three Jesuits (Campion, Ralph Emerson, and Persons); and two laymen (Thomas Bruscoe and John Pascal). The mission was intended to be a spiritual in focus, but the Second Desmond Rebellion, which began in July 1579 with the landing of papal troops at Smerwick harbor in Ireland, immediately implicated the missionaries as possibly forging a second front. ${ }^{35}$

29 Godfrey Anstruther, The Seminary Priests: A Dictionary of the Secular Clergy of England and Wales 1558-1850, Vol. 1: Elizabethan 1558-1603 (Ware: St Edmunds College, 1968), 375, 153 .

$30 \quad$ Bartoli, Dell'Istoria della Compagnia di Giesu, 292.

31 Andreas Le Glay, Cameracum Christianum ou histoire ecclésiastique du diocèse de Cambrai (Lille: Lefort, 1849), 103.

32 Knox, Douay Diaries, 274.

33 Knox, Douay Diaries, 8.

34 Knox, Douay Diaries, 138.

35 For the mission, see Thomas M. McCoog, The Society of Jesus in Ireland, Scotland, and England 1541-1588: "Our Way of Proceeding"? (Leiden: Brill, 1996); Gerard Kilroy, Edmund Campion: Memory and Transcription (Aldershot: Ashgate, 2005); Gerard Kilroy, "Paths Coincident': The Parallel Lives of Dr Nicholas Sander and Edmund Campion, S.J," Journal of Jesuit Studies 1, no. 4 (2014): 520-41. 
Allen was back in Rheims on April 2, 1580. On Sunday, April 17, he entertained for lunch an English spy by the name of Charles Sledd, who had been in Rome during his Allen's sojourn there, and whom he followed to Rheims. (On his way to Rheims, Sledd stopped in Paris, to apprise Sir Henry Cobham, the English ambassador, of the impending mission to England and related matters. ${ }^{36}$ Following the meal, Sledd was invited to attend the afternoon sermon, scheduled to be delivered at 3 o'clock by Hart. The sermon was to be in English, following an innovation recently introduced by Allen, "in order to acquire greater power and grace in the use of the vulgar tongue, a thing on which the heretics plume themselves exceedingly, and by which they do great injury to the simple folk." 37

According to Sledd, the preacher selected as his theme the passion of Christ, vividly impressing on his auditors the necessity to suffer "some grefes," whereby they "might merite [their] salvation the more." The pope instructed them to return to England and "expell heresie," and Hart felt "bound to persuade \& exorte" those about to set out on the mission "to stand fyrme \& stedfastlye." Hart loudly pronounced his desire to join the missionaries, "vowinge rather to dye than to yeld to the hereticall \& abhominable proceedings of the Q: Majestie \& her Counsell." Sledd further heard Hart proclaim that all means were "lawfull" in the battle for the re-conversion of England. The pope had excommunicated Queen Elizabeth and urged the Spanish king to invade England "with fyer and sworde in the behofe \& name of the Pope," and woe to those who were not Catholics then. Hart concluded his sermon, Sledd added, by exhorting his colleagues "never to denye any thinge touchinge their faithes \& belefes \& to dye martirs as manye had done before them," further exhorting them not to reveal the names of Catholics is apprehended, for if they did, "they should be damned without doubte \& be as an excommunicated person." 38

When delivering his fiery sermon, Hart probably did not expect that his stated wish was about to be granted. Goldwell and Morton arrived in Rheims on May 24, with the rest of the group following a week later. By then Goldwell and Morton opted out of the mission, fearing that their landing in England might greatly endanger the mission-owing to Goldwell's known efforts to secure the excommunication of Elizabeth, and Morton's involvement with the Northern Rebellion. In their stead, Allen appointed Hart, Humphrey Ely (d.1604), and Thomas Cottam (1549-82). To increase their chances of eluding capture, the missionaries divided themselves into five smaller groups, and set out for England through different routes. Hart, Cottam, and Ely left Rheims on

\footnotetext{
36 Talbot, Miscellanea, 241.

37 Knox, Douay Diaries, $\mathrm{xl}$.

38 Talbot, Miscellanea, 242-43.
} 
June 5 , headed for Dunkirk, where they embarked on a ship to Dover. Landing on June 16 or 17, Hart and Cottam were immediately apprehended-Hart because he was mistaken for the layman Henry Orton. Revealing his true identity, Hart was transported to the court, then at Nonsuch, by a deputy to the governor of Cinque Ports, Thomas Andrews, who pocketed one hundred shillings for his trouble. ${ }^{39}$ Hart is our source of what happened next. Being "a very comely young gentleman" - he related to Robert Persons following his release- "his father and friends well known, and his talents greatly liked" by Sir Francis Walsingham (1532-90), his captors "would fain have gotten or perverted him by sweet means." Discharged "on a surety," Hart was allowed to proceed to Oxford for three months, "upon condition that he should confer" with Rainolds "about controversies of religion." Hart accepted the offer, he later averred, partly because he wished to see his family and "settle better his temporal affairs," and partly because he feared "little whatsoever John Reynolds or any other could say in defence of heresy against the Catholic religion." When the three months expired, Hart presented himself to Walsingham "as resolute in his religion as before, and somewhat more by the weakness he had perceived in his conferences," notwithstanding that his opponent "was one of the best the other side had." In the face of such resolve, Hart boasted, Walsingham dispatched the obdurate Catholic to Marshalsea prison; later he was removed to the Tower, where he was "used most barbarously."40

While confined to the Marshalsea, Hart continued to court confrontation. According to Allen's published account, Robert Hopton (1551-1607), the knight marshal, challenged Catholic prisoners to submit "questions as they would defend" in a disputation. Sherwin, Hart, and James Bosgrave (1547-1623) "offered themselves to the combat" and submitted their topics. These failed to please Hopton, who set alternative topics, to which the three consented. However, the day before the appointed time-December 4, according to Hart's diarySherwin was transferred to the Tower and the disputation cancelled. ${ }^{41}$ On December 24, 1580, the Privy Council ordered the transfer of Hart and Bosgrave to the Tower as well, with specific instructions regarding their examination: "If they shall refuse to answere plainely and directly unto the interrogatories, then may they bring them unto the tortures, and by terrour thereof wring from them the truthe of suche matters as they shall finde moste necessarye to be discovered." 42

\footnotetext{
39 Knox, Douay Diaries, 166; Anstruther, Seminary Priests, 91.

40 Morris, Troubles of Our Catholic Forefathers, 2:28-29.

41 Allen, A Briefe Historie, 81; Brian A. Harrison, A Tudor Journal: The Diary of a Priest in the Tower, 1580-1585 (London: St Pauls, 2000), 38 and 38n2. 
Hart was interrogated on December 29 and a document containing "extracts" of his answers reveals that he furnished details concerning many Continental Catholics, including the tasks with which they had been charged. Heading the list are Martin and Allen, the former of which, Hart divulged, had assigned him to deliver the seditious sermon at Rheims. Hart also named William Gifford and Robert Middlemore as having attended the occasion. An interesting differentiation of his fellow missionaries follows. Whereas Thomas Cottam, Ralph Sherwin, Edward Rishton, Luke Kirby, Humphrey Ely, Robert Johnson, Henry Orton, Robert Kent, John Mitchell, John Paschall, and Hart himself were appointed by Allen "to teach the Catholique faith in England," Lawrence Johnson, Thomas Clifton, Robert Coxe, Roger Wakeman, Stampe, Robert Persons, Edmund Campion, and John Short were enjoined to impart "Poperie." A long list of exiled Catholics and their whereabouts follows. ${ }^{43}$

A far more substantive interrogation took place two days later, in which Hart disclosed details concerning Catholic machinations to depose Queen Elizabeth. Part of the testimony was incorporated into a memorandum by the Protestant propagandist Thomas Norton (1532-84), dealing with the defense of Mary Queen of Scots's claim to the English throne, recently republished in Latin by John Leslie, bishop of Ross. ${ }^{44}$ According to Norton's narrative, Catholic grandees had concluded that the English would be far more receptive to an English nobleman replacing Elizabeth than to either a Scot or a foreigner. Hence it had been decided that Elizabeth should be deposed on grounds of heresy and "unlawfull birth," and that the pope would confirm the election of the nobleman who replaced her. That person must be a Catholic, of an illustrious family, and a bachelor (or widowed). Once on the throne he is to wed Mary Queen of Scots, and their son would inherit the throne. The Jesuits and the seminary priest were entrusted with the task of preparing the people for such an eventuality. "This confedaracie," Norton continued,

and all these articles thereof have ben confessed in the Tower by Hart, who was the persone of all the Seminarians most nere in secretes $\mathrm{w}^{\text {th }}$ Allen, and he confesseth that Allen him self did shewe him these articles, and did cause him to write them out, and that Allen receved them from Rome written with hand wherein Allen receved his ordinarie intelligences from the Pope $\mathrm{w}^{\mathrm{ch}}$ he supposeth to be the hand of Doctor Owen Lewes.

43 BL MS Add. 48035 , fols. $179-80^{\mathrm{v}}$.

44 John Leslie, De titulo et iure serenissimae principis Mariae Scotorum Reginae (Rheims: Foigny, 1580). 
Hart, however, refused to name the nobleman in question, "pretending that he knewe it not." His interrogators persisted, asking him to name that person whom the seminarians liked the most. "To that question he made no direct answere but gave commendacon to the L. Henrie Howard"- the younger brother of Thomas Howard, $4^{\text {th }}$ duke of Norfolk, and the future $1^{\text {st }}$ earl of Northampton $(1540-1614) \cdot{ }^{45}$

Hart was further queried about Pius V's (r.1566-72) bull of excommunication, and the instructions given to Campion and Persons regarding its interpretation. The bull, Hart explained, "remaineth in force, but in some points touching the Subjects it is altered by the present Pope," on account of the cruel dilemma it presented English Catholics: if they obeyed the queen "they bee in the Popes Curse," while disobeying her would place them "in the Queens danger." Consequently, Gregory XIII "hath altered that part of the Bull, and dispensed with them to obey, and serve her, without peril of excommunication."46 From the second extract, we learn that Hart revealed that during the previous February William Allen — with whom Hart "was verie inward" - had received a letter from Rome concerning an audience the pope had given the ambassadors of Spain and Florence. The three

agreed on a league against the Queene of England; $\mathrm{w}^{\text {ch }}$ articles by D. Allen's commandment he [Hart] copied out, and was forbidden to use anie speech of the articles. The effect of $\mathrm{w}^{\mathrm{ch}}$ articles was, that the Realme shall be invaded by 20,000 men and the most part at the King of Spaines charge; that her Matie should be deposed, some Englishe catholique elected king, \&c. ${ }^{47}$

Catholic writers, in particular, have been at pains to dismiss as fictitious allegations regarding the formation of a papal league in 1580 . They noted that Allen was still in Rome when the audience granted by the pope to the Spanish and Tuscan ambassadors had purportedly taken place, which made it unnecessary to inform him of it in a letter; besides, details regarding such an audience

45 BL MS Add. 48029, fols. 6o-61.

46 TNA SP 12/144, fols. 130-31 (original and copy). Published in William Cecil, Lord Burghley, The Execution of Justice in England (London, 1583), sig. C.ii. For the bull and its interpretation, see Recusancy and Conformity in Early Modern England: Manuscript and Printed Sources in Translation, ed. Ginevra Crosignani, Thomas M. McCoog, and Michael Questier (Toronto: Pontifical Institute, 2010), 86ff.

47 Hatfield House, Cecil Papers 138.80, fols. 212 ${ }^{\text {r-v }}$. The testimony was used in late June 1585 during the proceedings against Henry Percy, $8^{\text {th }}$ earl of Northumberland. 
had circulated prior to Hart's interrogation. ${ }^{48}$ Assuming, therefore, that the plot was bogus - perhaps manufactured by the government-what remains unexplored is why did Hart confess "under oath" to his copying a letter which included such information? Rather than supposing that the government simply affixed his name to a fabricated document, it seems more likely that in this particular instance the terrified prisoner was willing to acquiesce to instructions set by his captors. According to Hart's "Tower Journal," the interrogation of December 31 took place "after five days sleeping on the bare earth," and after he was "led to be tortured on the rack." As the modern editor of the journal had noted, the vague phraseology was designed to deceive. Since all other references to the rack involved the actual torture of fellow prisoners, Hart's presenting himself as being "led to be tortured on the rack" insinuates he endured a like fate. ${ }^{49}$ Hart himself admitted, as we shall see below, that he never suffered actual torture on the rack; in all likelihood, the intention was to intimidate him. A letter sent from the Tower by a fellow prisoner, perhaps Edward Rishton, appears to corroborate this reading: Hart "lay stretched upon this bed of torture [the rack] for three hours: but for the time being he was not in any other way or more grievously tortured." ${ }^{50}$ It should also be noted that the diary, or parts of it, was written after the events described, with the intention of portraying the diarist in a favorable light-most likely in an effort to conceal his less than heroic conduct while in prison. Regardless, insofar as Hart was concerned, life in the Tower proved relatively uneventful during the first eight months of 1581. Each prisoner, Hart related, had been allocated his own cell and his own guard, "who always keeps him under observation, preventing him from seeing and speaking with others and making any communications." ${ }^{\text {1 }}$ The reality may have been somewhat less bleak: both Hart and other prisoners managed to communicate with each other, as well as to smuggle letters to friends outside. Occasionally, they even managed to convert visitors — or even guards, as did Hart.

Following Campion's capture, and his arrival in the Tower on July 22, 1581, the judicial and executive branches of the government went into high gear. After twice subjecting Campion to the rack, the Privy Council staged on August 31 a

48 John H. Pollen, The English Catholics in the Reign of Queen Elizabeth: A Study of Their Politics, Civil Life and Government (London: Longmans, 1920), 234-43; L. Hicks, An Elizabethan Problem: Some Aspects of the Careers of Two Exile-Adventurers (London: Burns \& Oates, 1964), 223-34; CSP Venice, 7:649-51; Kilroy, Edmund Campion, 174-85.

49 Harrison, Tudor Journal, $38-39$.

50 TNA SP $12 / 149 /$ fol. 144, translated in St. George Kieran Hyland, A Century of Persecution under Tudor and Stuart Sovereigns from Contemporary Records (London: Keegan Paul, 1920), 266. The copyist misspelled Hart's name as Alart. 
public disputation between Campion and two Protestant ministers. The morning session was all Campion; in the afternoon, several other Catholic prisoners joined in. According to John Strype, Hart and Sherwin "spake frequently on the side of Campion and his arguments." ${ }^{52}$ The official account of the afternoon debate records two such instances. First, on whether Luther had denied in the preface of the first edition of his German Bible the canonicity of St. James's Epistle, calling it a "straw epistle" - a repudiation that was excised from subsequent editions of the Bible. Hart recalled that while in Rome, he had heard Robert Bellarmine (1542-1621) "affirme that that the wordes reported by Campion in his booke were in that preface of Luther, and that therefore upon his worde it was so." Later, when the Protestant ministers invoked Cardinal Cajetan's (1469-1534) endorsement of the distinction made by St. Jerome between Old Testament canonical and apocryphal books, Hart fired back: Cajetan was undoubtedly a good schoolman, but "when hee began to become an expositor of the scriptures [...] then he lost his grace and credit." ${ }^{n 3}$

The other three disputations-September 18-27-appear to have involved Campion alone. ${ }^{54}$ A fifth debate, scheduled for October 13, had been cancelled as members of the Privy Council lost confidence in the value of such spectacles. Instead, Campion was put to the rack again, on October $3^{1}$ and November 2. Hart himself was interrogated on November 3 , but only part of his testimony survives, where he elaborated on what he had revealed on December $31,1580.55$ Two weeks later he and fourteen other Catholic prisoners were put on trial. Hart, along with six other priests, was indicted on November 17, and put to trial on November 21; all, saved one, were condemned to death. Campion and seven other Catholics had been handed the like verdict a day earlier. ${ }^{56}$

52 Strype, Annals of the Reformation, 2/2:361; During the conference with Rainolds, Hart mentioned his attendance at the disputation, but did not elaborate: John Rainolds, The Summe of the Conference Betwene John Rainoldes and John Hart Touching the Head and the Faith of the Church (London: George Bishop, 1584), 47.

Alexander Nowell, A True Report of the Disputation or Rather Priuate Conference Had in the Tower of London, with Ed. Campion Iesuite, the Last of August 1581 (London: Christopher Barker, 1583), sig. Ciiii, Dii. According to the account of Sir Thomas Tresham, who attended the disputation, Hart also pointed out that Augustine had accepted the canonicity of the epistle: James V. Holleran, A Jesuit Challenge: Edmund Campion's Debates at the Tower of London 1581 (New York: Fordham University Press, 1999), 93.

54 For the disputations, see Kilroy, Edmund Campion, 271-97; Holleran, Jesuit Challenge.

55 Pollen and Macmahon, eds., The Ven. Philip Howard Earl of Arundel 1557-1595, 293; Hatfield House, Cecil Papers MS 138.80 fol. 212 ${ }^{\mathrm{v}}$.

$5^{6}$ It is quite possible that the fiery sermon Hart delivered at Rheims on the eve of the mission, was used as evidence against him. Alexander Briant was accused for merely 
On the morning of December 1, 1581, already tied — or about to be tied— to the hurdle that was prepared for dragging him, alongside Campion, Sherwin, and Alexander Briant, to their place of execution at Tyburn, Hart recanted. Back in his cell, he drafted a supplicatory letter to Sir Francis Walsingham, which has greatly discomforted Catholic hagiographers ever since it came to light in 1865 . Hart proposed to demonstrate his conformity and his "dutiful obedience towards Her Majesty" by turning spy and helping to expose the "great matter" that the pope designed for England. William Allen would have been best informed of such plans, and finding means "to know the very secrets of his whole heart" would prove most beneficial for Walsingham. Hart presented himself as perfectly suited for the task. Having been "so dear unto him before," Allen would undoubtedly "understand of my stoutness that it hath been such as to abide a whole year and more, close imprisonment, and that in the Tower." Allen would also presume that Hart had "been at the rack"; he would also comprehend that his protégé had been "indicted, arraigned, and condemned" like the other missionaries. Surely, then, once released, Allen would undoubtedly make Hart "privy to very many things," which previously he had "kept secret."57 The proposition fell on deaf ears. Rather than set Hart loose, Walsingham chose to square him off with Rainolds for a private conference. Years later, Hart availed himself of Walsingham's resolution as a means to conceal his faintheartedness-blaming his captors for preventing him from attaining the crown of martyrdom. As Persons related Hart's reconstruction of the events, he had been spared because the authorities wished to pervert "a young man of such rare ability and good family." They were unsuccessful; Hart "remained firm" and was ultimately banished from England. ${ }^{58}$

Hart stuck to such an alternative narrative of events for the rest of his life, even making it public in the preface he contributed to the published version of his conference with Rainolds, dated July 7,1584 . Hart stated that the manuscript had been ready for the press twelve months earlier, but he had "hindred the comming of it foorth." The Tower diary for June 19, 1583 confirms the statement: "John Hart [...] thrown into the Pit for forty days," for "refusing to agree" with Rainolds, clearly indicating an effort by the prisoner to bargain for his

attending Hart's "trayterous Sermon." Anthony Munday, A Breefe Aunswer Made Unto Two Seditious Pamphlets (London: John Charlewood, 1582), sig. Ciiir ${ }^{\mathrm{r}-\mathrm{v}}$.

57 TNA SP 12/150/80, fols. 148-49. I used the modernized version printed in Harrison, Tudor Journal, $163-65$. Sledd confirmed in the previous year that Hart "was dalye in the companye of [...] Alline \& of his Counsell," enjoying "good credite with him” (Talbot, Miscellanea, 244).

$5^{8}$ John H. Pollen, "Father Persons' Memoirs," Miscellanea IV (London: Burns \& Oates, 1907), 73 . 
freedom in return for granting permission to publish. ${ }^{59}$ Hart proceeded to narrate the alternate version of the events leading to the genesis of the book. More than two years earlier, Walsingham had granted him the "libertie of conference," first in Oxfordshire and then in prison. After he had been condemned to death, Walsingham "ceased not still to offer [Hart] the same favour." He accepted the offer, Hart feigned, for he grounded himself "upon the most certayne foundation of the Church so strengthened by God that it shall stand for ever." Walsingham summoned Rainolds and left instructions that Hart should be furnished with books. Glossing over the bargain he wished to strike with Walsingham, Hart also failed to mention his initial reluctance to accept Walsingham's alternative plan, for which he was punished in early January 1582 . As the tower diary makes clear: "John Hart, priest, because he refused to co-operate with the heretics in any way after his condemnation, was sent to the Pit for nine days." 60 A fellow prisoner, Luke Kirby, also noted the reprisal in a letter dated January 10, 1582: Hart "had many and great conflicts with his adversaries," and on that very morning he "was committed to the dongeon, where he now remaineth $[\ldots]$ the cause was for that he would not yeld to Maister Reignoldes of Oxford, in any one point, but still remained constant the same man he was before and ever. Maister Reignoldes, albeit he be the best learned of that sort [...] yet the more he is tried and dealt with all the lesse learning he hath shewed."61 Perhaps the reaction of family members to his clemency contributed to Hart's defiance. As Allen apprised Alfonso Agazzari, rector of the English College, RomeFebruary 7,1582 , Hart's mother visited him in the Tower, and encouraged her son to martyrdom, while William Hart was distressed to learn how his brother had failed to die alongside Campion. ${ }^{62}$

I shall return to the conference with Rainolds below. First, however, it should be noted that at the same time Hart sought to atone his momentary apostasy by seeking admission to the Society of Jesus. On May 13, 1582, he supplicated Jasper Heywood (1535-98), the superior of the mission, on the matter, intimating that, though he reneged on his initial determination to join the order, he had now regained his former yearning. The traumatic events of December 1, 1581, in particular, moved him deeply; the example set by Campion and the prospects

\footnotetext{
59 Rainolds, Summe of the Conference, 9; Harrison, Tudor Journal, 57.

6o Harrison, Tudor Journal, 5 o.

61 Allen, Briefe Historie, 120. The Latin version was published in John Gibbons, Concertatio Ecclesiae Catholicae in Anglia adversus Calvinopapistas \& Puritanos (Trier: Edmund Hatotus, 1583), 269 .

62 William Allen, The Letters and Memorials of William, Cardinal Allen (1532-1594), ed. Thomas F. Knox (London: David Nutt, 1882), 113 .
} 
of his own death had provoked a saintly impatience in him - joined with agony for having been denied martyrdom then and there. But as he was strapped with Campion to the hurdle, he was consoled by the prospects of fulfilling Campion's old desire to see Hart become a Jesuit. Indeed, Hart added, Campion appeared to him in a dream and enigmatically admonished him; which Thomas Cottam interpreted as a sign to proceed with his new vocation. ${ }^{63} \mathrm{Hey}-$ wood dispatched Hart's letter to Allen, together with his own recommendation, and Allen forwarded Hart's letter to Agazzari 2 March 2, 1583, urging him to show it to Superior General Claudio Acquaviva (in office, 1581-1615), because that "constantissimi confessoris" had dedicated himself to the order. ${ }^{64}$ Allen discussed Hart's application in earlier letters, too. Thus, on October 20, 1582, he informed Agazzari that Hart expected the crown of martyrdom and he desired to join the Jesuit order from prison. ${ }^{65}$ On May 18, 1583 , Acquaviva acquiesced. Several individuals had urged him to admit Hart into the order, he intimated to Allen, and Hart's own letter requesting admission had given him "no small edification." Formerly, Acquaviva had felt reluctance to do so, but those reasons "have ceased," and the general became convinced that Hart's "fortitude and purity of intention have by long tribulation been refined as by fire," and he deserved whatever "consolation" was in his power. Allen was given permission to inform Hart that if "he preservers in his desire," he should be notified "that we hereby enrol him amongst us." 66

Hart promoted his case by direct and indirect shifts, which bordered duplicity. Consider the crafty self-presentation in a letter to Allen, dated November 15, 1582. He did not seek to furnish "grief and tears," Hart wrote, but impart matters that should "give cause for special rejoicing and praise." Thus, for example, though small in stature, Arthur Pitts and George Haydock fought, and were still fighting "in this conflict for truth and religion." They were not alone; three laymen have "shown themselves braver than many priests," while two other laymen "were racked nearly to death," and yet their torturers failed to extract anything of them. Hart then interjected himself into this worthy mix"of myself I dare make no profession"-before summarizing that all of them

63 Bartoli, Dell'Istoria della Compagnia di Giesu, 293.

64 Allen, Letters and Memorials, 176; ARsI, Fondo Gesuitico 648, 309.

65 Allen, Letters and Memorials, 166. For other instances of members of the secular clergy seeking admission to the order "in articulo mortis" (at the point of death), see Thomas H. Clancy, S.J., "The First Generation of English Jesuits, 1555-1585," Archivum historicum Societatis Iesu 57 (1988): 137-62, at 140, 142, 144.

66 Patrick Ryan, S.J., "Some Correspondence of Cardinal Allen, 1579-85; from the Jesuit Archives," Catholic Record Society, Miscellania VII (London: Burns \& Oates, 1911), 12-105, at 91. 
remained "steady in the faith." Hardly surprising, then, to find Allen "greatly comforted" by such an edifying account. ${ }^{67}$

All along, the persecution of Catholics continued. On April 2, 1582, while John Paine (1532-82) awaited his execution at Chelmsford, a Protestant minister charged him with treason, despite his protestations to the contrary. Campion and his companions, too, reasoned the minister, had denied charges of treason, and yet they were confuted by two witnesses. When Paine retorted that Campion avowed to him, just before his execution, that the charges were imaginary, the minister persisted: "Harte also confessed it." ${ }^{68}$ Six weeks later, on May 13, 1582, ten prisoners in the Tower were required to respond to six articles: 1) Whether the bull of Pius V was "a lawfull sentence, and ought to be obeyed by the subjects of England. 2) Whether Elizabeth was a lawful queen "and ought to be obeyed" notwithstanding the bull. 3) Whether the pope had the power to authorize rebellion against the queen - as he had done and continued to do. 4) Whether the pope had the power to discharge subjects from their allegiance to their rulers. 5) Whether the writings of Sanders and Bristow in support of the bull were true or false. 6) In view of the pope's bull, which side "ought a good subject of England" take in the event that a Catholic force invaded the country? Characteristically, Hart proved evasive on all questions and, he alone, refused to subscribe his name to his responses. ${ }^{69}$

The authorities immediately published the responses, which greatly aggrieved James Bosgrave and Henry Orton, who were cited as having denied that the bull and the sentence of excommunication were lawful, and who purportedly further stated that the queen ought to be obeyed no matter what the pope decreed. The matter appeared serious enough for the other prisoners to take extreme measures. Months earlier, Hart had managed to convert one of the guards. This was Samuel Kennett, who had been Christopher Marlowe's contemporary at King's School, Canterbury. In 158o, barely eighteen years old, Kennett left school and was appointed yeoman warder in the Tower, where he served for a while as Campion's guard. Bernardino de Mendoza, the Spanish ambassador to England, described him as early as April 11, 1582 as a "most terrible Puritan," who "was won over, and is now firmly resolved to suffer martyrdom, if necessary, for the Roman Catholic religion."70 Undoubtedly, the Catholic

67 Ryan, "Some Correspondence," 73-75.

68 Allen, Briefe Historie, 136.

69 A particular declaration or testimony, of the undutifull and traiterous affection borne against her Maiestie by Edmond Campion Iesuite, and other condemned Priestes, witnessed by their owne confessions (London: Christopher Barker, 1582), sig. D.i.

70 William Urry, Christopher Marlowe and Canterbury, ed. Andrew Butcher (London: Faber \& Faber, 1988), 49; Calendar of Letters and State Papers relating to English Affairs / 
prisoners considered it advantageous to conceal Kennett's conversion, but the publication of $A$ Particular Declaration — probably in late May-necessitated a response, so Hart drafted his own version of the events and dispatched Kennett to carry it to Rheims. The youth arrived there on June 23, in time for Allen to include, in a letter to Agazzari, the news regarding Kennett's arrival, and Bosgrave and Orton's disavowals of the testimonies attributed to them. One wonders whether it was Allen who immediately arranged the publication of A censure upon the answeres of $\mathrm{Mr}$. Bosgrave and Mr. Orton, and then arranged for the smuggling of the small pamphlet into London, where it was found July 6 on the porch of St Giles without Cripplegate Church. ${ }^{71}$

Whether his testimony displeased his captors, or whether he again refused to cooperate with Rainolds, on May 28, 1582, Hart was again condemned to death. However, the previous day, the Privy Council instructed the lieutenant of the Tower to leave Hart behind "for certaine good consideracions" - the nature of which remains unclear. ${ }^{72}$ Not surprisingly, Hart failed to mention the incident in his Tower diary. To a certain extent, Allen was aware of his protégé's dissimulation. It was he who published Paine's exchange with the Protestant minister, so he was undoubtedly briefed on aspects of Hart's testimony. We may also surmise from his response to Burghley's Execution of Justice in England that Allen knew that Hart had not been put to the rack. Whereas he inveighed against the torture of other inmates, Allen cited only harsh confinement when mentioning Hart. ${ }^{73}$ Furthermore, Anthony Munday divulged in one of his polemical writings that when Campion and his fellow prisoners denied that they were enjoined to closely follow Bristow's motives, they were rebutted by the information that Hart had avouched for the verity of the directive. Finally, the Catholic prisoners were confronted with Hart's admission that he copied the letter Allen had received from Rome, and Allen may well have heard about this, too-for he angrily refuted the verity of the report. ${ }^{74}$

Elizabeth: Preserved Principally in the Archives of Simancas, Vol. 3: 1580-1586, ed. Martin A. S. Hume (London: Eyre and Spottiswoode, 1896), 336.

71 Allen, Letters and Memorials, 146-47. Allen identified Hart as the person who converted Kennett in a subsequent letter: Allen, Letters and Memorials, 205. For the pamphlet, see Foley, Records of the English Province of the Society of Jesus, 3:292-94.

72 Dasent, ed., Acts of the Privy Council of England, 13:428.

73 William Allen, A True, Sincere and Modest Defence, of English Catholiques That Suffer for Their Faith (Rouen: Parson's Press, 1584), 14. Worth noting is that the Latin translation of this work, Ad persecutores Anglos..., was made by William Reynolds, John's Catholic brother.

74 Anthony Munday, A discouerie of Edmund Campion, and his confederates, their most horrible and traiterous practices [29 January 1582] (London: John Charlewood, 1582), sig. B.viv; C.iiv; Allen, True, Sincere and Modest Defence, 19-20. 
But to return to Hart's account of his conference with Rainolds. After debating orally for some ten weeks during the early months of 1582 - and all this time Hart persisting in his "former mind"-Rainolds decided to commit the exchanges into writing, so that "he might see the groundes on which [Hart] stood." They both drafted summaries of their positions, with Hart furnishing references to authors "whose judgement and learning" he preferred to his own. As the notes proved too terse for anyone but themselves to comprehend, Hart asked Rainolds to expand the summaries into a full-blown narrative-he "being troubled then with more necessary cogitations of death" - promising to peruse the text when completed "and allow of it, if it were to my mind; or otherwise correct, if I misliked ought in it." Rainolds embarked on the task, sending Hart draft sections as soon as he completed them. After receiving Hart's comments, Rainolds entered whatever changes Hart requested. But when the time came to send the manuscript to press, Hart balked "for some considerations which seemed to [him] very great and important," and requested to revise his own contribution. Permission was granted, and he was furnished with whatever books he requested. Once Hart had his "owne speeches \& reasons perfitted," he acknowledged that "he hath set downe herein a true report of those things which past in conference betweene us, according to the grounds and places of the autours, which I had quoted \& referred my self too." Hart concluded by acknowledging that he had, indeed, stated that the pope "may not depose princes."75

The acknowledgement was made toward the end of the conference. Having demonstrated to his own satisfaction the nullity of arguments regarding papal supremacy over councils, Rainolds turned to a related topic: "Princes are supreme governours of their subjects in things spiritual, and temporall." In response to Hart's protestations that rulers may not deal with matters touching God, Rainolds invoked Scripture as evidence that the civil magistrate had always been charged with punishing "evill doers in things concerning God." The supremacy given the prince in matters ecclesiastical, Rainolds explained, meant "not to preach the word, minister the sacraments, celebrate the prayers, or practise discipline of the Church, but to provide that these thinges be done, as they ought, by them whem God hath called thereto: we give to Caesar no more then is Caesars." And since "every lawfull Prince is the supreme governour of his owne subjects in thinges spirtiuall and temporal," Allen, Sander, and Stapleton were wrong to reprove the queen's supremacy "as wicked and ungodly." Indeed, Rainolds crowed, during their initial oral conversations Hart himself admitted-after perusing Nowell's The Reproufe of M. Dorman his 
proufe of certaine Articles in Religion (1566) - that he "had mistaken our doctrine of that point True, Hart acknowledged. He subscribed because Nowell granted rulers no more than St. Augustine did: in their realms, kings serve God if they "commaund good things, \& forbid evil; not only concerning the civil state of men, but the religion of God also." But this was as far as Hart was willing to go. When Rainolds pressed him to prove "that the faith which we professe in England is not the Catholike faith," the prisoner balked: "Ye Catholike faith is $\mathrm{y}^{\mathrm{e}}$ which we professe in $\mathrm{y}^{\mathrm{e}}$ Church of Rome. [...] I wil confer no farder herof, unles I have greter assurance of my life." Hart had already received such an assurance, Rainolds replied. He ought rather say that he would "conferre no farder unlesse [he] had better assurance of [his] cause." And committing Hart to God's grace the conference ended. ${ }^{76}$

In his address to the "Students of the English Seminaries at Rome and Rhemes," Rainolds forecasted that the superiors of those institutions would probably not permit their charges to read the book, notwithstanding it had been they who desired it. Moreover, Rainolds taunted, they had already claimed victory in John Gibbons's Concertatio Ecclesiae Catholicae in Anglia (1583). Though "the lernedst" of the heretics, it was claimed, Rainolds had shown himself "so much the more unlerned," the "more earnestly" he had been dealt with. Hart, by contrast, was portrayed as "a noble champion of Christ, and a holy Priest [...] [who] had taken deeper roote in the foundations of the faith, and was of sounder lerning." If they believe their own brags, Rainolds chided, the superiors of the seminaries ought to permit their charges to peruse the book; if they don't, one may well "suspect that these glorious speeches of their own scholers, and base wordes of us, are but sleights of policie."77

The Summe of the Conference appeared in late summer 1584. Some weeks later, the queen and her ministers decided to banish twenty-one seminary priests and Jesuit prisoners; on January 21, 1585, they were transported across the Channel. After their arrival in Rouen, Bosgrave headed to Bourges, while Heywood proceeded to Rheims; Persons and Hart followed him several days later, arriving to the English College by March 22. ${ }^{78}$ In a lost letter to Acquaviva dated March 3, 1585, Persons apparently "wondered whether he should be dismissed because of his views." 79 The general decided against it. Bosgrave's testimony

76 Rainolds, Summe of the Conference, 669-74.

77 Rainolds, Summe of the Conference, 16; Gibbons, Concertatio Ecclesiae Catholicae in Anglia, 326-27.

78 Letters of William Allen and Richard Barret, 145.

79 McCoog, "Robert Persons and Claudio Acquaviva: Correspondence," 165; Persons, Correspondence, 576; McCoog, Touching Our Society, 140. 
of 1582 "tarnished the Society's reputation" and merited banishment. Yet, he opted for clemency on account of Bosgrave's "long incarceration, his recognition of his mistake, and Parsons's intercession in his favour." Significantly, no qualms concerning Hart seem to have been raised. Just the opposite. Persons undoubtedly commended his friend, and apprised Acquaviva of his intention to travel to Rome, to which the general responded warmly in the same letter: "We highly approve of his coming to Rome $[\ldots]$ he will be so much the better a worker in the Lord's vineyard." 80

It is unclear to what extent was Persons aware of Hart's failings. What is certain is that it was he who helped shape Hart's posthumous reputation as a long sufferer for the Catholic cause-albeit not quite a martyr. Persons acknowledged that Hart himself had furnished the details concerning his captivity in conversations the two held in France and in Rome. Nor can it be determined whether Hart was selective or deceitful with the information he imparted to Persons; or whether Persons made virtue out of necessity. Regardless, Persons's letters and memorials became the source upon which subsequent Catholic historians would draw. Persons was almost certainly responsible for the publication of Hart's Tower journal, too. It was not included in the first edition of Nicholas Sander's De origine ac progressu schismatis Anglicani (1585), edited by Edward Rishton; it first appeared in the 1586 Rome edition. Though it has been argued that William Allen prepared the revised version of Sander's own work, ${ }^{81}$ Persons's involvement in the production of the volume need not be discounted. He and Allen travelled from Rheims to Rome together, arriving there on November 4, 1585, and they undoubtedly collaborated on the project. Hart himself arrived in Rome a week later-having spent several months at the Jesuit novitiate in Verdun - and he remained in town throughout the first half of $1586 .{ }^{82}$ It is not unlikely, therefore, that Hart actually drafted the short diary during that time, either at the behest of Persons and/or Allen, or in order to further exculpate himself. The book was published by mid-May $1586,{ }^{83}$ shortly before Hart left for Poland. Hart's death on July 19, 1586, soon after his arrival there, undoubtedly facilitated the construal of an edifying hagiography - to

8o McCoog, "Robert Persons and Claudio Acquaviva: Correspondence," 163-64; Persons, Correspondence, $5^{85}-87$. For a draft of Acquaviva's letter to Hart, see ARSI, Francia 1/I, fols. $226^{\mathrm{v}}-227^{\mathrm{r}}$.

81 Joseph Simons, Robert Persons, S.J., “Certamen Ecclesiae Anglicanae”: A Study of an Unpublished Manuscript (Assen: Van Gorcum, 1965), 300-5.

82 Monumenta Angliae: English and Welsh Jesuits; Catalogues, 2 vols. (Rome: Institutum Historicum Societatis Iesu, 1992), 2:348.

83 Persons sent a copy of the book to Don Juan de Idiaquez, Philip II's secretary of state, on May 20, 1586: Persons, Correspondence, 632. 
which a final component was added in 1594, following the transfer of Hart's remains to a different resting place. As it had been reported, the body of the Englishman, "tortured for the faith on the rack," was found seven years later to be incorrupt. ${ }^{84}$

Subsequent hagiographers and historians have improved on Persons's depiction of Hart's sufferings during his four-year incarceration. Henry More (1586-1662) described how Bosgrave and Hart were dragged from Marshalsea to the Tower, "to be tried not by discussion but torture." 85 A fellow Jesuit, Bartoli, went further. He devoted quite a few evocative pages of his Dell'istoria della Compagnia di Giesu l'Inghilterra (1667) to narrating the sufferings of the spirited Hart; his triumph over Protestant theologians; and the sincerity of his faith. ${ }^{86}$

Bartoli, and subsequent scholars, either praised Hart's performance in the conference with Rainolds, or downplayed the significance of the debate, and the concession Hart made. Case in point, the estimation of Hugh Tootell (aka Charles Dodd) (1672-1743): "Dr. Rainolds assures the reader, that the conference was publish'd by Mr. Hart's consent; but this does not obviate misrepresentation. The force of proofs and objections are easily disguised, and entirely lost, when managed by an adversary." ${ }^{17}$ Recent scholars followed suit, lessening Rainolds's accomplishment. Thomas McCoog, for example, followed John Pollen in suggesting that the debate with Hart was permitted "because Hart was not an exceptionally gifted man," ${ }^{88}$ while Questier concluded that "Hart appears to make no theological concessions in the hundreds of pages of dispute, something at which Catholics rejoiced." ${ }^{\prime \prime 9}$

It cannot be denied that the conference with Rainolds was carried out on unequal terms. But it is also clear that Hart, unlike Campion, was furnished with books, and he was allowed to dictate certain terms regarding the

84 Monumenta antiquae Hungariae, Vol. 2: 1580-1586, ed. László Lukács (Rome: Institutum Historicum Societatis Iesu, 1976), 1001n4.

85 Henry More, The Elizabethan Jesuits: Historia Missionis Anglicanae Societatis Jesu (166o) of Henry More, ed. Francis Edwards (London: Phillimore, 1981), 174, 176-77.

86 Bartoli, Dell'Istoria della Compagnia di Giesu, 293, cited in Morris, The Troubles of Our Catholic Forefathers, 32.

87 Hugh [Charles Dodd] Tootell, The Church History of England, from the Year 1500, to the Year 1688. Chiefly with Regard to Catholicks, 3 vols. (Brussels [i.e. Wolverhampton], 1737-42), 2:145.

88 Pollen, The English Catholics in the Reign of Queen Elizabeth, 338; McCoog, The Society of Jesus in Ireland, Scotland, and England, 146.

89 Michael C. Questier, Conversion, Politics, and Religion in England, 1580-1625 (Cambridge: Cambridge University Press, 1996), 159. 
composition and revision of the book. Equally to the point, Hart seems to have suffered harsher conditions only during his occasional bouts of conscience, during which he refused to abide by the terms of the agreement he made with Walsingham. And while the published version of the Conference includes only one explicit concession made by Hart, it is evident that on quite a few issues Hart was unable to match Rainolds's historical scholarship-not only because Rainolds was the better scholar, but because the evidence, on some of the contested issues, contradicted Hart's claims. ${ }^{90}$

9o For a fuller discussion, see my "John Rainolds: Critic and Translator," in Labourers in the Vineyard of the Lord: Erudition and the Making of the King James Bible, ed. Mordechai Feingold (Leiden: Brill, 2018), 105-59. 